\title{
Outlaws of the Marsh: Confucianism Inside and Swordsman Outside The Development of Swordsman and Confucianism Culture in Outlaws of the Marsh
}

\author{
Min Dong* \\ Rizhao Polytechnic, China Rizhao 276826, China.
}

\begin{abstract}
Outlaws of the Marsh not only presents a world of Jiang-hu (literally rivers and lakes, term which refers to the environment where the martial artists live) for the public, but also presents a cultural complex, including rangers, Confucianism, Buddhism and Taoism. Among them, the "righteousness" of ranger culture and the "loyalty" of Confucian culture are the main body of Outlaws of the Marsh. The combination of overt and covert constructs a Jiang-hu of "Outlaws of the Marsh" for readers.
\end{abstract}

Keywords: Traditional Literature; Outlaws of the Marsh; Culture Research

From the Northern Song Dynasty to the Ming Dynasty, Outlaws of the Marsh has gone through "the origin of Song Jiang", "the circulation of storybooks", "the spread of Yuan-Dynasty Zaju" and "the finalization of novels". It is a collection of folklore, artist rendering and literati art processing, and constitutes a work of multi-cultural integration. It includes knight errant culture, Confucian culture, Buddhist culture, Taoist culture and so on, among which knight errant culture and Confucian culture are shown as the main culture. In Outlaws of the Marsh, the swordsman culture is dazzling, and the Confucian culture is hidden. Obvious part and hidden part complement each other. It is both fusion and agitation, but ultimately it is unified, which constitutes a different charm of "Outlaws of the Marsh Culture".

\section{The criterion of swordsman and Confucian culture}

To explore the topic of Swordsman and Confucian culture in "Outlaws of the Marsh", the first thing is to define a clear theoretical paradigm of the swordsman and Confucian culture, and then definite target shown. Culture is a common belief and code of conduct pursued by a certain group in a certain region. Thus, the culture of swordsman and Confucianism should also have its own beliefs and norms.

Historical Records · Biography of the Ranger can be regarded as the first work describing and commenting on the folk ranger in China. Shi Qian believed that the "rangers" at that time were people who kept their promises, helped the poor, did not fear life and death, and indifferent to fame and wealth. The so-called "rangers must keep their word when they speak, be resolute when they do things, and realize what they have promised, to show their honesty. They are willing to sacrifice their lives to help others in danger. They have gone through the test of life and death, but they don't boast about their skills or their merits." In a word, it is a highprofile work, low-key life ${ }^{[1]}$. Their attitudes towards Gang up and bully the weak and free from desire are abhorrent. Han Yunbo, a contemporary scholar, believes that Chinese swordsman culture has the social characteristics of "folk heroes", "between heroes and hooligans" and "righteousness and personality"[2]. Generally speaking, swordsman culture takes "faith and righteousness" as the standard, and emphasizes the extreme of maintaining the noble personal morality. Moreover, because this "personal moral high ground" produces a strong "exclusiveness", that is, everything that conflicts with its "personal morality" is opposite and can be attacked or even destroyed of violence or non-violence. Therefore, they let swordsman make them energetic, commit themselves to a promise of great wealth, and go through fire and water. They are "heroes" when they are correctly displayed; they are "hooligans" when they are wrongly displayed.

Confucianism has a long history, and "Outlaws of the Marsh" from the story to the text of the novels, coincides with the development of Neo-Confucianism in the Song and Ming Dynasties. As an important branch of Confucianism in this period, Neo-Confucianism in the Song and Ming Dynasties took ethics and morality as the core, inherited the authentic Confucianism of Confucius and Mencius, and integrated Taoism and Buddhism, and tried to achieve the goal of governing the country. The purport of the theory lies in the recognition of the legitimacy of ethical values and norms in society and in the individual selfconsciousness of the subject's morality ${ }^{[3]}$. Therefore, Neo-Confucianism in the Song and Ming Dynasties played both positive and negative roles in maintaining autocratic rule, suppressing and killing people's natural desires, attaching importance to subjective

Copyright (C) 2020 Min Dong

doi: 10.18282/l-e.v9i4.1721

This is an open-access article distributed under the terms of the Creative Commons Attribution Non-Commercial License (http://creativecommons.org/licenses/by-nc/4.0/), which permits unrestricted non-commercial use, distribution, and reproduction in any medium, provided the original work is properly cited. 
will and moral integrity. Its theoretical and practical value has undoubtedly influenced "Outlaws of the Marsh". The influence of Neo-Confucianism in Song and Ming Dynasties is obvious. For example, the starting point of the behavior of "only against corrupt officials, not against the emperor", the love between men and women giving way to "physical fitness", placing women in a very low subordinate position, fraternal loyalty is the most important, and so on, the behavior of the heroes in Outlaws of the Marsh all contain the theoretical traces of Neo-Confucianism in the Song and Ming Dynasties.

\section{The presentation of swordsman and Confucian culture in Outlaws of the Marsh}

After clarifying the theoretical framework and practical characteristics of swordsman culture and Confucian culture, we can explore at this culture presented in Outlaws of the Marsh.

"Acting on behalf of heaven" is the purpose and orientation established for the organization after Song Jiang presided over Liangshan. "Heaven" and "Tao" are two important concepts in Confucian philosophy. The "heaven" here can point to the abstract heaven, namely heaven, providence, the emperor, etc., or the concrete heaven, namely the emperor, also known as the "Zhao Guanjia (Refers to the Song Dynasty Zhao surname emperor, especially refers to the Song Taizu, Zhao Kuangyin)" in the mouth of Ruan's three heros. Or it can also point to the common "heaven" both abstract and concrete. The emperors of the feudal dynasty were all "act in heaven's stead", calling themselves "the son of heaven", deified, humanized into one. "Tao" is not only "the way of heaven", but also "humanity", which refers to moral principle, reason, morality and so on. In the view of the Song Jiangs, since the Northern Song court was ruled by treacherous officials and corrupt officials, and "heaven" or "son of heaven" could not do anything for various reasons, it should be the folk heroes to promote the "'moral principles" of the ideal. The phrase "on behalf of" shows Song Jiang's realistic helplessness and heroism. Throughout the development of the storyline of Outlaws of the Marsh, Song Jiang always takes the Confucian "heaven" and "Tao" as the center, and acts in the way of swordsman. The swordsman acts of robbing Shengchen Gang (goods transported in batches in the Tang and Song Dynasties), righteous interpretation, rescuing, gathering in the mountains and forests, strengthening the team, accepting offer amnesty and enlistment to rebels and so on are all for the sake of justice for "heaven" or "son of heaven". Even if they attack cities and seize land and recruit people by any means, they can also be regarded as Song Jiang, Wu Yong and other "rogue" means to develop the organizational power of "acting for heaven". In this process, Confucianism and swordsman are closely integrated or deviated from each other, but they are perfectly integrated in the end.

In response to "acting on behalf of heaven", the Song Jiangs "only fight against corrupt officials, not against the emperor." In Liao Erwa (The ancient name of Dongping Lake in Shandong Province) Ruan Xiaoqi's Fishing Song "cruel officials are killed, loyal to repay the Zhao Guanjia" sings the aspirations of Liangshan heroes. Although there were a few reckless and ignorant people, such as Li Kui, who strongly opposed the recruitment and chanted the slogan of "going to the capital and seizing the throne" - which can be regarded as the sprout of Liangshan organization's political ideas and demands for political power - they soon declined under the strong pressure of Song Jiang and others. It is because whether we gather in Liangshan or offer amnesty and establishment to rebels to transform into a "government army" has never been divorced from the consideration of "heaven" and "Tao". For example, Song Jiang, who was a petty official, was well versed in literature, and was familiar with the books of sages. Naturally, his thoughts and beliefs and code of conduct could not be separated from the paradigm of "Confucianism". He was killed several times, rescued several times, and refused to join the gang several times, all of which reflected his own Confucian influence. He was very concerned about his "innocence" and at least did not want to stand on the opposite side of the court. Once he was forced to go to Liangshan, he tried his best to guide all the heroes to go all the way to "offer amnesty and establishment to rebels" in order to be loyal to the emperor. This is Song Jiang's "Confucian" side; however, people called him "Baoyi (protecting justice)", supporting justice and wealth, releasing Chao Gai, and continual introducing talents to Liang Shan, which is contrary to his political identity and political integrity, which is also his "swordsman" side. Shami Huailin and Jin Shengtan regarded Song Jiang as a traitor of "false Taoist, true robber". Their comments fully reflect the collision of "swordsman" and "Confucianism" in Song Jiang. However, if we understand Song Jiang's political ambition, we can see from his Xunyang River poems that "It is just like a tiger lying on a barren hill, lurking in the claws to endure", "If he is so ambitious, he dares to laugh at Huang Chao's lack of backbone", As well as his personal inner monologue, "Although I have been given a false name, I have not been able to achieve it and I have not been able to accomplish it. On the contrary, it has been written on my cheeks and deserves to be here." It can be seen that Song Jiang, no matter "doing justice for heaven" or "fighting against corrupt officials rather than against the emperor", all took "Confucianism" as the center, "swordsman" as the code of conduct, and used the "swordsman" behavior to realize the inner pursuit of "Confucianism". Besides Song Jiang, Wu Yong is also such a similar person. Wu Yong is a scholar who has read a lot of poems and books, but he is keen to get to know the heroes in Jiang-hu and make plans for a career. It can be said that Wu Yong plays an indispensable role in the development of Liangshan. But he was also such a Confucian scholar and literati who sought to realize his personal ambition through the way of "swordsman".

There is a person in Liangshan hero is very interesting, he is Li Jun known as Hun Jianglong. Different from Song Jiang and $\mathrm{Wu}$ Yong, Li Jun was born in the three tyrants of Jieyang. However, he was very discerning, very aware of the situation, was the convinced by Fei Bao "There are not many days left", successfully retired, found a quiet place to settle down to the end of the day, in accordance with the Confucius said, "Dangerous states do not enter the chaotic states do not live", "If there is a way in the world, you will come out to be an official; if there is no way in the world, you will live in seclusion". Li Jun is also a typically act as "swordsman" but true "Confucian".

However, we have to say that the heroes of Liangshan also have extreme behaviors in their hearty fighting. The most typical is the "indiscriminate killing" plot of Outlaws of the Marsh. Such as Wu Song's killing without reason get carter in Yuanyang Building, Li Kui's cutting off the front row in Jiangzhou's court, killing the old and young of Hu family after conquering Zhujia 


\title{
Effective Interventions on Reading Fluency for Students with Learning Disability
}

\author{
Yujia Gao* \\ Xi'an Eurasia University, Xi’an, Shaanxi 710065, China.
}

\section{Introduction}

The purpose of this article is to consider applying some intervention methods to help students with learning disability to improve their reading fluency. It begins by introduce the definition, components as well the importance of reading fluency. Then followed by the review of related literature, introducing research methods, processes and results in detail. Finally, it concludes with discussions and implications about the effective intervention programs.

\section{The definition and importance of reading fluency and its' instruction of students with learning disability}

Reading fluency refers to three levels that includes word, syntactic and passage level ${ }^{[1]}$. And it is also defined as a bridge between the two major components of reading - word decoding and comprehension ${ }^{[2]}$." Teaching and intervention of reading fluency of students with learning disability has become a problem. So the main research problem of this paper is:

What kinds of interventions can be applied to help students with learning disability?

\section{Research done by chard and elias on the research problem.}

(1) Chard's research about effective intervention programs.

In Chard's research, the stress of the intervention program mainly targets at word level and content level of elementary-age students who have learning disabilities. And after yielding 104 related studies, he divided the intervention program into two kinds: repeated reading and word practice interventions with more detailed branches.

In repeated reading part, four models are presented. They are: "repeated reading without a model", "repeated reading with a model", "repeated reading interventions with multiple features", and "other elements that influence fluency performance in

Copyright (C) 2020 Yujia Gao

doi: 10.18282/1-e.v9i4.1722

This is an open-access article distributed under the terms of the Creative Commons Attribution Non-Commercial License (http://creativecommons.org/licenses/by-nc/4.0/), which permits unrestricted non-commercial use, distribution, and reproduction in any medium, provided the original work is properly cited.

Village, Song Jiang's idea of "killing Zhujia Village" and so on. This is of course the negative side of "swordsman" of heroes, but as mentioned above, chivalrous men often take safeguarding their personal moral interests as the yardstick. They are used to dividing the non-self-moral into hostile forces. Wu Song spared no effort to "be happy, love and revenge", Li Kui for the sake of brotherhood morality and freedom, and Song Jiang for the sake of village spirit and reputation. This can also be regarded as a manifestation of the agitation of "swordsman and Confucianism" in Outlaws of the Marsh, but it still takes "Confucianism" as its core.

\section{Confucianism inside and swordsman outside in the "Outlaws of the Marsh" world}

To sum up, the relationship between "swordsmen culture" and "Confucian culture" contained in Outlaws of the Marsh should be based on "Confucianism" inside and "swordsmen" outside. In other words, "Confucianism" is the spiritual core of "Outlaws of the Marsh" and "swordsman" is its behavior choice. Whether it is the purpose of the organization or the concept of the activity, it fully reflects this point. Of course, this "Confucianism" is not the "benevolence" and "self-denial and restoration of rites" of Confucianism's classics, but the loyalty to the imperial power emphasized by Neo-Confucianism in Song and Ming Dynasties. "swordsman" is the man of Jiang-hu divided by Han Yuanbo.

\section{References}

[1]Sima Qian. Records of the Historian[M]. Beijing: China Publishing House, 1959.

[2]Han Yunbo. On the basic characteristics of Chinese chivalrous culture[J]. Journal of Southwest Normal University (Philosophy and Social Sciences), 1993; (1): 104-110.

[3]Shen Yuwen, Sha Jingjing. Development and Contemporary Significance of Neo-Confucianism in Song and Ming Dynasties[J]. Anhui literature, 2008; (7): 373-374. 